\title{
Primary Packaging and Stability Evaluation of a Serum Used for the Periorbital Area of the Sensitive Eye
}

\author{
ANDREI CATALIN MUNTEAN ${ }^{1 *}$, ANCA MARIA JUNCAN ${ }^{1 * \#}$, DANA GEORGIANA MOISA ${ }^{2 *}$, ANDREEA LOREDANA VONICA ${ }^{1}$, \\ LUCA LIVIU RUS ${ }^{1 \#}$, CLAUDIU MORGOVAN ${ }^{1 \#}$, FELICIA GABRIELA GLIGOR ${ }^{1}$, ANCA BUTUCA ${ }^{1}$, ADRIANA STANILA ${ }^{3}$ \\ 'Lucian Blaga University, Faculty of Medicine, Preclinical Department, 2A Lucian Blaga Str., 550169, Sibiu, Romania \\ ${ }^{2}$ S.C. Laboratoarele Fares Bio Vital S.R.L., 50 Plantelor Str., 335700, Orastie, Romania \\ ${ }^{3}$ Clinica Ofta Total, 4 Semaforului Str., 550309, Sibiu, Romania
}

\begin{abstract}
The aim of this study was the development and formulating of an eye contour serum containing hyaluronic acid (HA) and the assessment of stability tests performed for the cosmetic product, transfered into a glass cosmetic bottle with polipropylene (PP) pump and cap. Sample of cosmetic serum were stored using 20 $\mathrm{mL}$ glass bottles with PP (Polypropylene) pump and cap. The developed cosmetic formulation was monitored under accelerated stability studies, performed over a period of 30 days while maintaining the product at 4 , 20 and $40^{\circ} \mathrm{C}$. Quality control initial, and after initiating the accelerated stability test was performed for the developed cosmetic formulation.
\end{abstract}

Keywords: eye contour serum, cosmeceuticals, cosmetic packaging, accelerated stability test

Dry eye disease (DED) represents one of the most widely spread pathology of the ocular surface. Dry eye is defined as a multifactorial disease of the tears and ocular surface that results in symptoms of discomfort, visual disturbance, and tear film instability with potential damage to the ocular surface. It is accompanied by increased osmolarity of the tear film and inflammation of the ocular surface [1-3].

Artificial tears represent one the most popular strategy for the treatment of DED. As dosage forms they are conditioned as drops, gels and ointments. On the pharmaceutical market the most common artificial tears used are drops, which are liquid dosage forms, but do not have a long contact time with the ocular surface. As active ingredients there are frequently used cyclosporine, natural compounds and hyaluronic acid/sodium hyaluronate. For better patient's compliance it is recommended to use gels as treatment regimen for an improved therapeutic effect $[1,2,4-7]$.

Hyaluronic acid (HA) is a polysaccharide that belongs to the glycosaminoglycan family and consists of a basic unit of two sugars, glucuronic acid and $\mathrm{N}$-acetylglucosamine. HA usually exists as a high molecular mass in the synovial fluid that surrounds joints, cartilage, and tissues of the eye and skin [8-10].

HA represents a key molecule in a variety of medical, pharmaceutical, nutritional and cosmetic applications, considering it's unique and physico-chemical properties and to it's safety profile. For this reason, HA is still widely studied to elucidate its biosynthetic pathways and molecular biology, to optimize its biotechnological production, to synthesize derivatives with improved properties and to optimize and implement its therapeutic and aesthetic uses. Molecular mass and circumstances of synthesis/degradation are the key factors defining $\mathrm{HA}^{\prime} \mathrm{s}$ biological actions. Figure 1 represents the medical, pharmaceutical, and cosmetic applications of HA and its derivatives [11-13].

From a legal standpoint there are three possibilities in dermatology to apply semi-solid formulations to the skin in the form of topical drugs, cosmetics or medical devices.

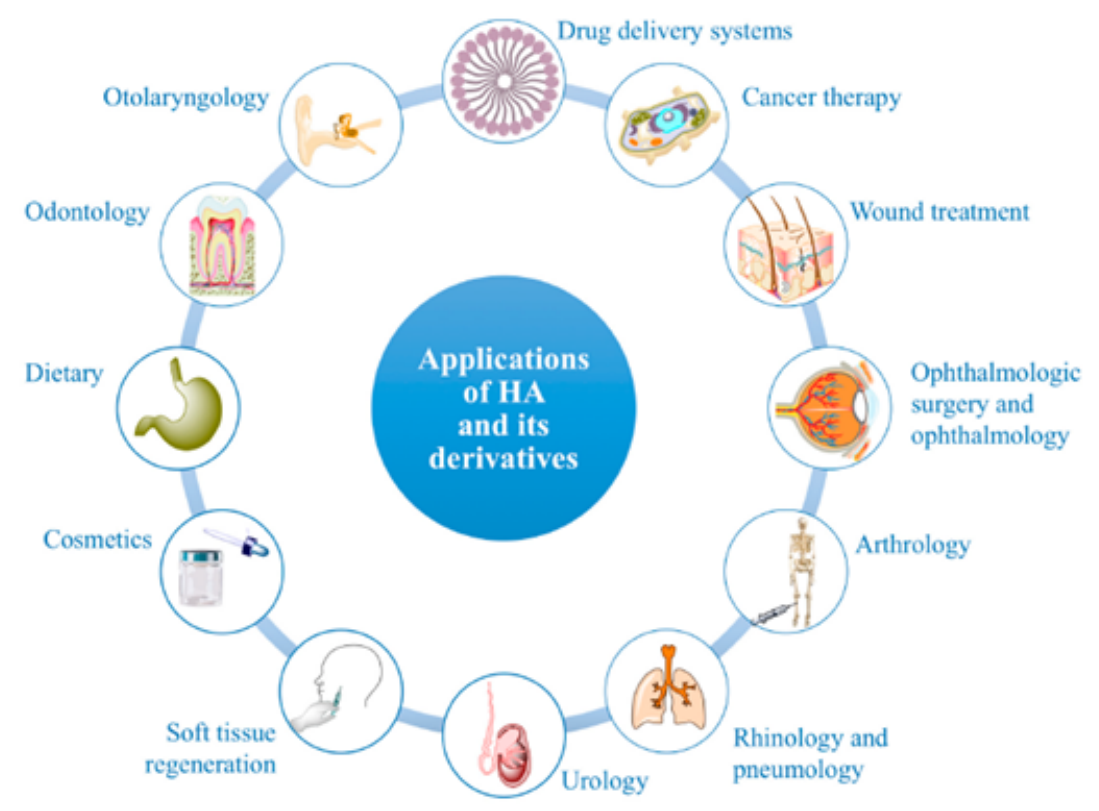

Fig. 1. Medical, pharmaceutical, and cosmetic applications of $\mathrm{HA}$ and its derivatives 
What law makers understand under the term drugs, cosmetics or medical devices is defined in the wording of the law [14].

The global definition of a therapeutic drug is quite similar, most agreeing that a drug is intended for the diagnosis, cure, mitigation, treatment or prevention of diseases via some means of physiological action. Towards to cosmetics, differences exist in major world markets including Australia, US, EU, Canada and Japan [15]. Cosmetics are commercially available products, that are used to improve the appearance of the skin and are defined as any substance or preparation intended to be placed in contact with the various external parts of the human body (epidermis, hair system, nails, lips and external genital organs) or with the teeth and the mucous membranes of the oral cavity with a view exclusively or mainly to cleaning them, perfuming them, changing their appearance and/or correcting body odours and/or protecting them or keeping them in good condition (EU Cosmetics Directive 76/778/ EEC and EU Cosmetic Products Regulation (EC) No. 1223/ 2009) [16-20].

Cosmetic formulations have complex composition and contain mixtures of ingredients. The properties and forms of cosmetics are decided based on the body part on which the product is to be used and whether is it to be rinsed off, wiped off, or left on, and so that users feel easy to use. Marketing aspects, such as containers and proposed lifestyles, may also be reflected in the properties and product forms. Main product forms include liquids, viscous liquids, milky lotions, creams, gels, waxes, solids, powders, and aerosols [21- 23].

Cosmetic products are currently regulated under the Cosmetic Directive 76/768/EEC and its amendments. Since 2009, the Cosmetic Regulation was adopted, 1223/2009/ EC, which replaces the above directive and comes into force on 11th July 2013. Medicinal Products for Human Use (pharmaceuticals) is regulated under Directive 2001/ 83/ EC and its amendments. Other regulations may also be applicable, such as Regulation (EC) 1272/2008, classification, labeling and packaging of substances and mixtures, and the General Product Safety Directive 2001/ 95/EC. The borderlines between the different product categories may be difficult to demarcate. The intended use, mode of action, composition, physiological properties, and the risks of use are the bases to determine which set of regulations should be applied to a topical formulation (fig. 2.) [24].

It is foreseen the potential for functional cosmetics to be a new class of compounds regulated probably under the same cosmetic legislation, with eventual additional requirements on safety and efficacy. This will be the recognition of the today market situation, where cosmeceuticals are largely represented [25]. Marketing of new cosmetics is a good way to increase the turnover of players on this market through pharmacies [26].

The new Cosmetic Regulation 1223/2009/EC also underlines the necessity of complete information concerning the safety assessment of the product, data about the side effects of the cosmetic formulation, together with stability details and compatibility with packaging materials [27].

The characteristics of the packaging materials that are in direct contact with the product must be assessed, as they may have an impact on the finished product's safety [28].

It is important to note that cosmetic products have primary, secondary and tertiary packaging. Primary packaging is that which is in direct contact with the product. Secondary packaging is a container that holds the primary packaging. In the case of premium skin care products, perfumes and colour cosmetics, it is usually cardboard or other casing thathouses the product on store shelves. Tertiary packaging is used for shipping, bulk handling and warehouse storage; it comprises cardboard boxes, as well as palettes for storage and shipping. Some examples of materials that are used in packaging are listed below:

-Metals (Aluminium)

-Glass

-Paper and paperboard

-Wood

-Plastics/polymeric materials

-Hybrid constructs:

- Plastics/polymeric materials + paper and paperboard

- Plastics/polymeric materials + metals [29].

The development of new and diversified packaging styles, and high potential in emerging economies provides huge growth opportunities for personal care products, create exciting opportunities within the packaging industry. Moreover, innovation in packaging plays a major role in driving the growth of cosmetic bottle packaging market.

Figure 3 presents by segment, the cosmetic bottle packaging market [30].

Most packaging regulations refer to the secondary component, or outer package- the package seen by the consumer at the time of purchase [31].

Packaging plays a critical role in almost every industry, sector and supply chain. However, the balance between amount and type of packaging vs. protection of product needs careful consideration [29].

The global market of cosmetic packaging was valued at USD 23 billion in 2015 and is forecasted to increase to 33 billion U.S. dollars in 2024 (fig.4.) [32].

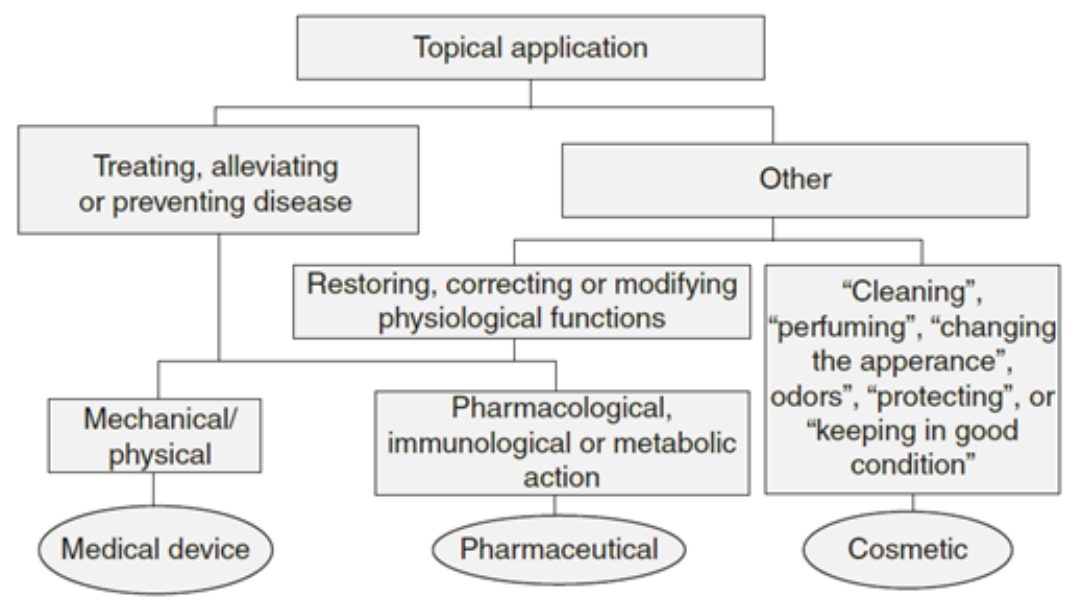

Fig. 2. Classification of a medical device, a pharmaceutical and cosmetic product 


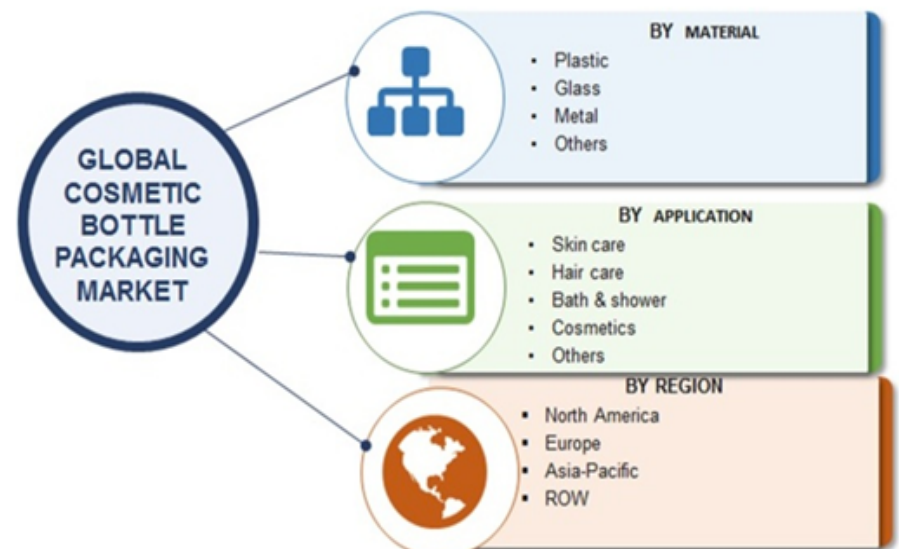

Fig. 3. Cosmetic Bottle Packaging Market, by segment

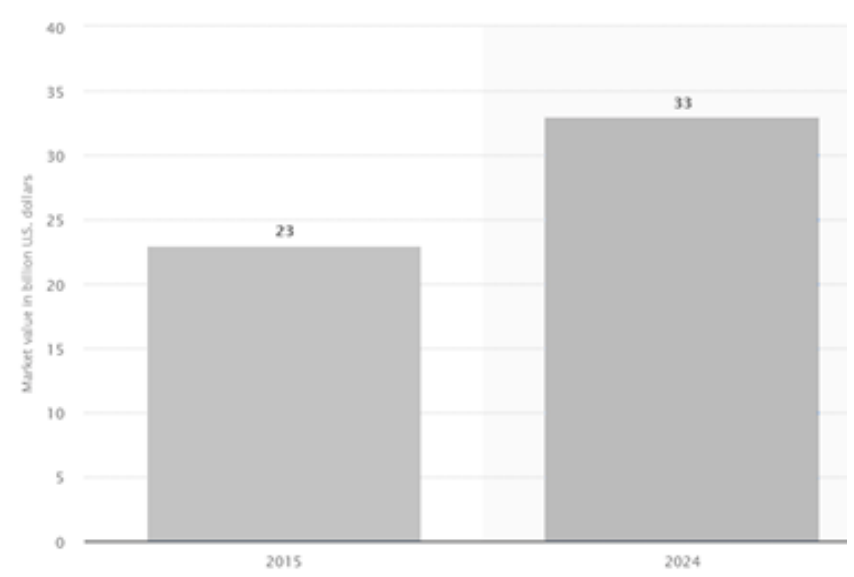

Fig. 4. Market value of cosmetic packaging worldwide in 2015 and 2024

The packaging industry is continuously evolving as medical and cosmetic product companies institute changes in the design, development, and manufacture of packaging systems. Cosmetics and pharmaceuticals each have their own special packaging requirements. Each product must be analyzed for stability in the package being considered for use by the manufacturer; changes in container material, resin formulation, color, and closure system can all affect product stability [33].

Chemical and physical stability testing of a product is an integral part of the development process. Its purpose is to ensure that the product meets the intended quality criteria, as well as functionality and aesthetics, when used and stored under normal or foreseeable conditions. Commonly used test conditions for physical and chemical stability are long-term storage at controlled room temperature, stress testing over several months at high and low temperatures, freeze-thaw cycles, as well as light exposure tests. Testing in the final package material is also performed to insure product/package compatibility [34].

\section{Experimental part}

\section{Materials and methods}

Preparation of the Relaxing Eye Serum

The ingredients used in the developed cosmetic formulation were: deionised water; Acrylates/C10-30 Alkyl Acrylate Crosspolymer (Azelis Romania Srl); Glycerin; Xanthan Gum (CP Kelco, Germany); Cetyl Alcohol, Glyceryl Sterate, PEG-75 Stearate, Ceteth-20, Steareth-20 (Gattefosse, France), Octyldodecanol (Sabo, Italy), Water, Sodium Hydroxide; Phenoxyethanol (and) Ethylhexylglycerin (Schülke \& Mayr GmbH, Germany); Hydrolyzed Hyaluronic Acid (Givaudan Active Beauty, France); Aqua (and) Sucrose Palmitate (and) Tocopheryl Acetate (and) Glyceryl Linoleate (and) Sodium Hyaluronate (and) Phenoxyethanol (and) Potassium Sorbate (and) Citric Acid (Givaudan Active Beauty, France); Water, Glycerin, Vaccinium Myrtillus FruitExtract (Crodarom, France).

Table 1 shows the composition of the developed eye serum(table 1).

Manufacturing procedure: Acrylates/C10-30 Alkyl Acrylate Crosspolymer was sprinkled over the water of phase $\mathrm{Al}$ and heated to $75^{\circ} \mathrm{C}$. Glycerine and Xanthan Gum

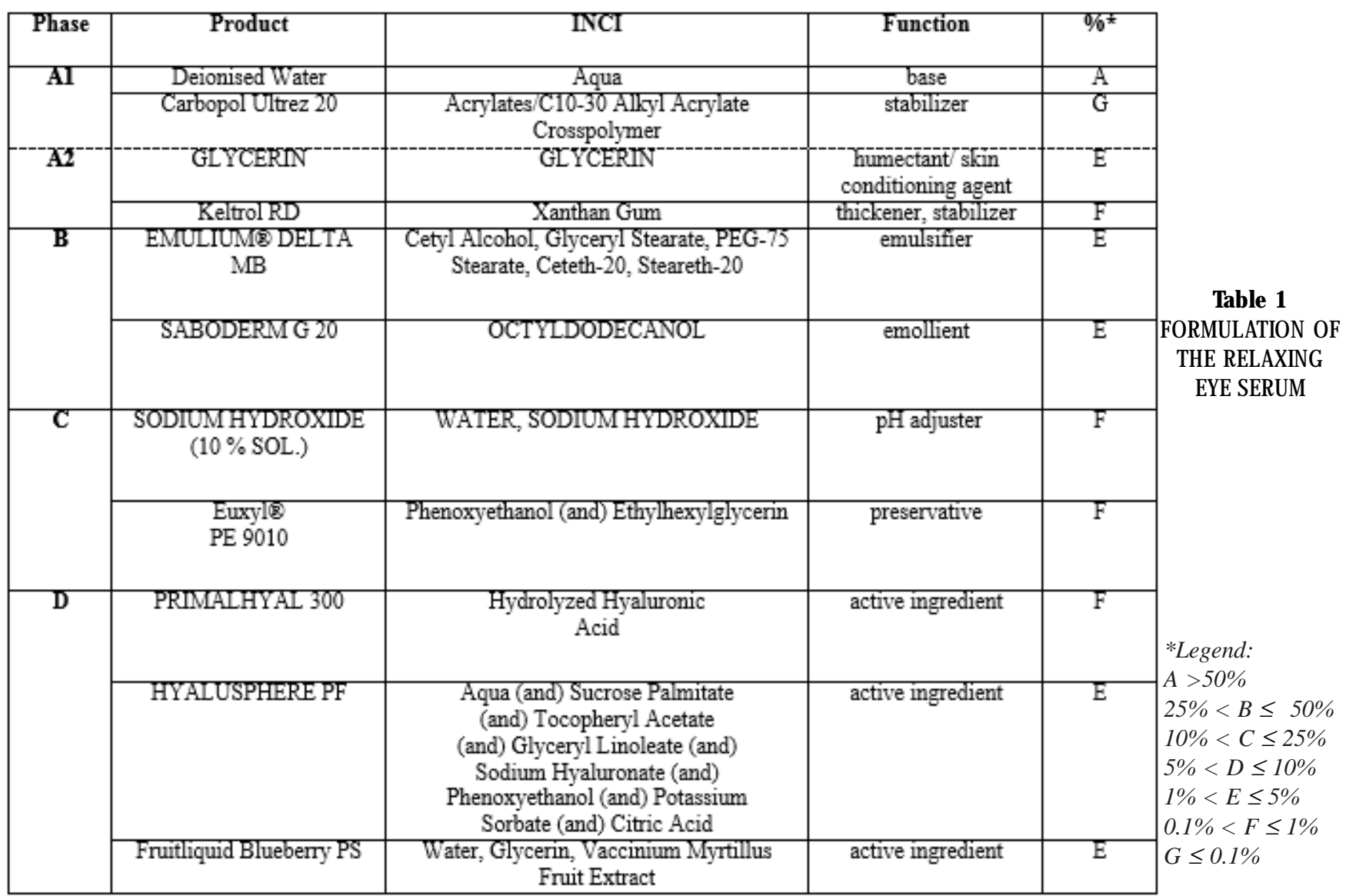


was added into $A 1$. Phase $B$ was prepared and heated to $70{ }^{\circ} \mathrm{C}$. Under rapid mixing (T-50-digital-ULTRA-TURRAX, IKA, Germany, 1500 rpm), phase B was added to A1+A2. Rapid mixing was mantained for about 5 minutes and neutralized with $\mathrm{C}$. Cooling was performed under mixing at about $30^{\circ} \mathrm{C}$, and phase $\mathrm{D}$ was added.

Ingredients: The complex Cetyl Alcohol, Glyceryl Stearate, PEG-75 Stearate, Ceteth-20, Steareth-20 at 2\% creates a soft milky serum. Glycerin and Octyldodecanol are moisturizing agents providing nourishment and soft feel without any greasy sensation. Carbomer and Xanthan Gum are gelling agents that help to stabilize. PrimalHyal ${ }^{\mathrm{TM}}$ 300 (Hydrolyzed Hyaluronic Acid) is medium molecular weight of hyaluronic acid pow der (MW: 100-300 KDa), and possess an activity of reinforcement of the skin natural defense, stimulation of beta-defensin release by keratinocytes and activation of skin cellular repair. HYALUSPHERE PF (Aqua (and) Sucrose Palmitate (and) Tocopheryl Acetate (and) Glyceryl Linoleate (and) Sodium Hyaluronate (and) Phenoxyethanol (and) Potassium Sorbate (and) Citric Acid) is encapsulated high molecular weight hyaluronic acid (1-1.4 MDa). Spherulites penetrate into the deepest cutaneous layers and progressively deliver hyaluronic acid in the target activity site for a long lasting effect. Hyalusphere vectorizes the HA in the deep skin layers to fill in wrinkles and smooth the skin [35]. Fruitliquid Blueberry PS (Butylene Glycol (and) Aqua (and) Vaccinium Myrtillus Fruit Extract) is used in the treatment of skin bleaching, irritated and reddened skin care. Itis rich in anthocyanidins and related compounds have been reported to possess antimicrobial, antioxidant, and antiinflammatory properties [36, 37].

Packaging of the cosmetic product

Samples of cosmetic serum were stored using $20 \mathrm{ml}$ glass bottles with PP (Polypropylene) pump and cap. Tehnical specification of the cosmetic bottle and pump are presented in table 2, respectively, figure 5 and table 3, respectively figure 6 , figure 7 . shows the tehnical specification of the cosmetic bottle, pump and cap ensemble.

Accelerated stability test

\begin{tabular}{|l|l|}
\hline \multicolumn{2}{|c|}{$\begin{array}{c}\text { Tehnical Specification } \\
\text { Cosmetic bottle } 20 \mathrm{~mL}\end{array}$} \\
\hline Material & Opal Glass \\
\hline Capacity & $18 \pm 2 \mathrm{~mL}$ \\
\hline Weight & $37 \pm 4 \mathrm{~g}$ \\
\hline Neck & $3 \mathrm{~mm}$ \\
\hline Thread Widh & $1.8 \mathrm{~mm}$ \\
\hline
\end{tabular}

Table 2 TEHNICAL SPECIFICATION OF THE COSMETIC BOTTLE

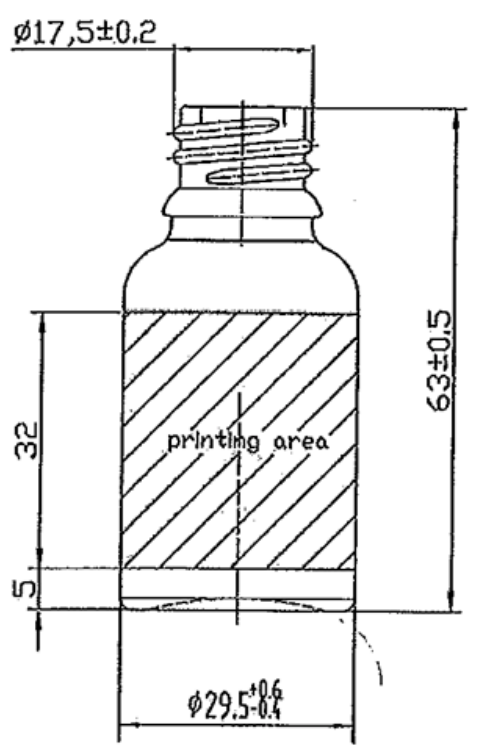

Fig. 5. Tehnical scheme of the cosmetic bottle
Table 3

TEHNICAL SPECIFICATION OF THE COSMETIC PUMP

\begin{tabular}{|l|l|l|}
\hline \multicolumn{3}{|c|}{$\begin{array}{c}\text { Tehnical Specification } \\
\text { Cosmetic pump }\end{array}$} \\
\hline \multicolumn{1}{|c|}{ No } & \multicolumn{1}{|c|}{ Name } & \multicolumn{1}{c|}{ Material } \\
\hline 1 & Actuator & PP \\
\hline 2 & Upper piston & LDPE \\
\hline 3 & Closure/Cap & PP \\
\hline 4 & Gasket & PP \\
\hline 5 & Lower piston & LDPE \\
\hline 6 & Stem insert & LDPE \\
\hline 7 & Mounting cup & PP \\
\hline 8 & Spring & Stainless Steel \\
\hline 9 & Housing & PP \\
\hline 10 & Ball & Glass \\
\hline 11 & Dip tube & HDPE \\
\hline RANGE OF DOSAGE & $130-230 \mu 1$ \\
\hline APPLICATIONAREA & Eye Care; Lip Care; \\
& & Facial Care \\
\hline
\end{tabular}

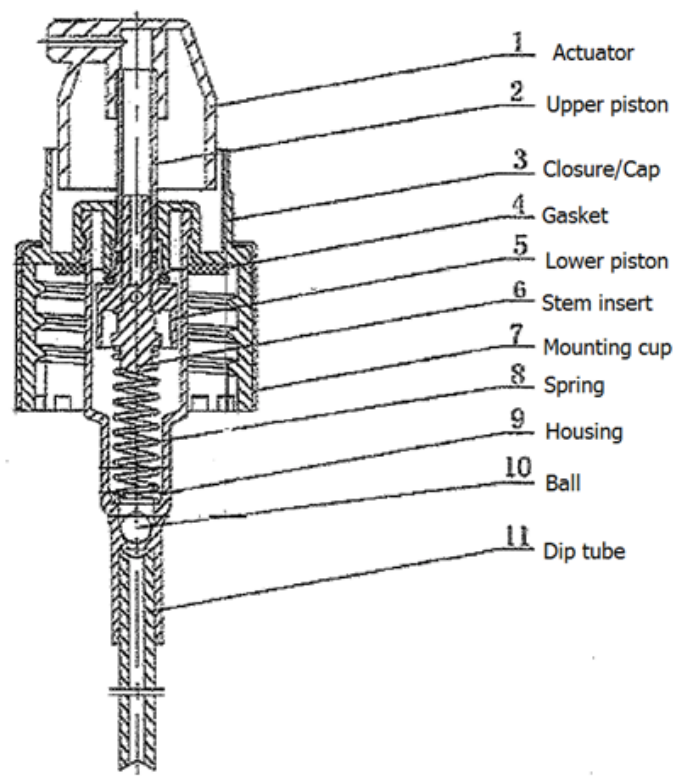

Fig. 6. Tehnical scheme of the cosmetic pump

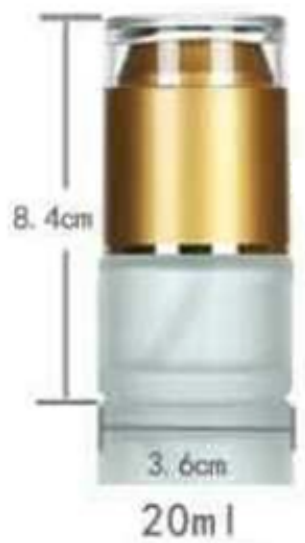

Fig. 7. Tehnical scheme of the cosmetic glass bottle and PP pump and cap ensemble
Product safety and compliance with regulatory requirements is essential and is factored into ingredient selection, final formula selection, and packaging choices to ensure that they are safe. Stability evaluation is conducted to ensure the cosmetic product formulation and packaging is compatible so that the product remains stable and safe [38].

Packaging can directly affect finished product stability because of interactions which can occur between the product, the package, and the external environment. Such interactions may include: 
-interactions between the productand the container (e.g. adsorption of product constituents into the container, corrosion, chemical reactions, migration);

-barrier properties of the container (its effectiveness in protecting the contents from the adverse effects of atmospheric oxygen and/or water vapor, and in ensuring the retention of water and other volatile product constituents).

Stability testing should include packaging which is made of exactly the same material(s) and is as similar as possible in all other respects to the package in which the product will be marketed [39].

The physical stability of the finished product should be established, ensuring that no changes in physical state of the finished product (e.g. coalescence of emulsions, phase separation, crystallisation or precipitation of substances, colour changes) occur during transport, storage or handling of the product. Indeed, exposure to changing temperatures, humidity, UV light, mechanical stress, etc. could reduce the intended quality of the product and the safety for the consumer.

Relevant stability tests, adapted to the type of cosmetic productand its intended use, should be carried out. To make sure that no stability problems are induced by the type of container and packaging used, physical stability tests are currently carried out with inert containers and those intended to be used on the market. Also potential leaching of substances of the packaging into the product should be investigated. Relevant physical and chemical parameters should be controlled for each batch of the finished product coming on the market [40].

A simple experimental design was employed, using glass bottles with polyethylene (PP) pump and cap and, filled with an developed eye serum formulation and submitted to different degradation tests (photostability test and accelerated stability test) to mimic stress conditions that products can meet during their shelf life, according to European guidelines for stability tests on cosmetic products $[17,18,41]$.

The developed cosmetic formulation was monitored under accelerated stability studies. Accelerated stability tests were performed over a period of 30 days while maintaining the product at 4,20 and $40^{\circ} \mathrm{C}$.

Quality control initial, and after performing the accelerated stability test consisted of the following determinations:

-the appearance, color and odor were tested organoleptically.

- $\mathrm{pH}$ determination was performed using a $\mathrm{pH}$ meter (Mettler Toledo, Schw erzenbach, Switzerland).

\section{Results and discussions}

A cosmetic serum was developed and accelerated stability testing was performed including primary packaging- glass bottles with PP pump and cap.

The developed cosmetic formulation is a soft white serum with a fluid and velvety texture, thanks to the encorporated emulsifier complex. High comfortis provided when applied on the skin and the finish is soft and relaxing, due to incorporation of Glycerine and Octyldodecanol in the cosmetic formulation. Fine lines are reduced and smoothed due to MW HA and encapsulated HA and Blueberry Extract.

Accelerated stability studies performed over a period of 30 days, while maintaining the product at $4^{\circ} \mathrm{C}, 20^{\circ} \mathrm{C}$ and $40^{\circ} \mathrm{C}$, showed that the formulated and studied cosmetic product is stable, and there was no deterioration of the glass bottle and PP pump and cap.
Table 4

PHYSICO-CHEMICAL CHARACTERISTICS OF THE DEVELOPED EYE SERUM

\begin{tabular}{|c|l|l|}
\hline \multicolumn{2}{|c|}{$\begin{array}{c}\text { Admissibility } \\
\text { conditions (initial) }\end{array}$} & $\begin{array}{c}\text { Admissibility conditions } \\
\text { (30 days) }\end{array}$ \\
\hline Appearance & white serum & concordant \\
\hline Odor & characteristic & concordant \\
\hline Color & white & concordant \\
\hline$p H$ & $5.5-6.0$ & $5.5-6.0$ \\
\hline
\end{tabular}

The cosmetic glass bottle and PP pump and cap manufacturer stated the conformity of the packaging ensemble according to the European Commision Regulation No. 10/2011, it's amendaments and Regulation No. 1935/2004.

Quality control of the developed cosmetic serum revealed: achieving an acceptable cosmetic preparation with elegant appearance and appropriate physicochemical and pharmacotechnical ( $p \mathrm{H}$, viscosity) characteristics. The determination results initial, and after 30 days are shown in table 4.

Further to the protocol developed in this study, it is possible to evaluate both, the behavior of the container itself, and the possible interactions between content and container in order to ensure the quality of product and the safety for consumers.

\section{Conclusions}

The cosmetic industry increasingly focuses on the development and formulating of active cosmetic products in which the packaging plays a crucial role in protecting its content during use. The above-proposed protocol has proved being a simple method for the evaluation of the stability of a developed eye serum transfered in a glass bottle with PP pump and cap.

The accelerated stability test performed in this study for the developed eye serum, showed that the formulated and studied cosmetic product is stable, the cosmetic product is compatible with the glass cosmetic bottle and PP pump and cap, and there was no deterioration of the packaging after the performed test. Quality control of the developed cosmetic serum revealed an acceptable cosmetic preparation with elegant appearance and appropriate physico-chemical and pharmacotechnical $(\mathrm{pH})$ characteristics initial, and after 30 days.

Acknowledgement: The author would like to express special thanks to cosmetic ingredients distributors and cosmetic packaging manufacturer for providing raw materials, respectively cosmetic packaging used for the development, formulation and packaging of the developed and formulated cosmetic product.

\section{References}

1.PINTO-FRAGA, J., LOPEZ-DE LA ROSA, A., BLAZQUEZ ARAUZO, F., URBANO RODRÍGUEZ, R, GONZALEZ-GARCIA, M. J., Eye Contact Lens., 43, 1, 2017, p. 57-63.

2.CRAIG, J. P., NICHOLS, K. K., AKPEK, E. K., CAFFERY, B., DUA, H. S., JOO, C. K., LIU, Z., NELSON, J. D., NICHOLS, J. J., TSUBOTA, K., STAPLETON, F., Ocul Surf., 15, 3, 2017, p. 276-283.

3.BARABINO, S., LABETOULLE, M., ROLANDO, M., MESSMER, E. M., Ocul Surf., 14, 3, 2016, p. 365-376. 
4.POSTORINO, E. I., RANIA, L., ARAGONA, E., MANNUCCI, C., ALIBRANDI, A., CALAPAI, G., PUZZOLO, D., ARAGONA, P., Eur J Ophthalmol., 28, 1, 2018, p. 25-31.

5.FOULKS, G. N., FORSTOT, S. L., DONSHIK, P. C., FORSTOT, J. Z., GOLDSTEIN, M. H., LEMP M. A., NELSON, J. D., NICHOLS, K. K., PFLUGFELDER, S. C., TANZER, J. M., ASBELL, P., HAMMITT, K., J ACOBS, D. S., Ocul Surf., 13, 2, 2015, p. 118-132. .

6.LOPEZ-DE LA ROSA, A., PINTO-FRAGA, J., BLAZQUEZ ARAUZO, F., URBANO RODRIGUEZ, R., GONZALEZ-GARCÍA, M. J ., Eye Contact Lens., 43, 6, 2017, p. 383-388.

7.FONDI, K., WOZNIAK, P. A., SCHMIDL, D., BATA, A. M., WITKOWSKA, K. J., POPA-CHERECHEANU, A., SCHMETTERER, L., GARHÖFER, G., J Ophthalmol., 4, 2018, p. 1-

8.NEUMAN, M. G., NANAU, R. M., ORUNA-SANCHEZ, L., COTO, G., J Pharm Pharm Sci, 18, 1, 2015, p. 53 - 60.

9.J ANIS, R., PATA, V., EGNER, P., PAVLAEKOVA, J., ZAPLETALOVA, A., KEJ LOVA, K., Biointerphases, 12, 2, 2017, p. 021006-1-021006-8.

10.VASILE, D., IANCU, R., BOGDANICI, C., UNGUREANU, E., CIOBOTEA, D., CIULUVICA, R., IANCU, G., Rev. Chim. (Bucharest), 68, no. 2, 2017, p. 384-386.

11.FALLACARA, A., BALDINI, E., MANFREDINI, S., VERTUANI, S., Polymers, 10, 7, 2018, p. 701-737.

12.LIAO, Y. H., JONES, S. A., FORBES, B., MARTIN, G. P., BROWN, M. B., Drug Deliv. , 12, 6, 2005, p. 327-342.

13.SALWOWSKA, N. M., BEBENEK, K. A., ZADLO D. A., WCISLODZIADECKA, D. L., J Cosmet Dermatol., 15, 4, 2016, 520-526.

14.KORTING, H. C., SCHOLLMANN, C., J Dtsch Dermatol Ges., 10, 2, 2012, p. 103-109.

15.***https://w w w. personalcaremagazine.com/story/3824/ cosmeceuticals-advertising-rules-and-claims (accesed on 07.07.2018). 16.J UNCAN, A. M., HODISAN, T., Rev. Chim. (Bucharest), 62, no. 4, 2011, p. 415.

17.JUNCAN, A. M., RUS, L. L., Mat. Plast.., 55, no. 3, 2018, p. 426. 18.J UNCAN, A. M., Mat. Plast., 55, no. 4, 2018, p. 644.

19.*** COUNCIL DIRECTIVE of 27 July 1976 on the approximation of the laws of the Member States relating to cosmetic products (76/768/ EEC), https://eur-lex.europa.eu/LexUriServ/LexUriServ.do?uri= CONSLEG:1976L0768:20080424:en:PDF (accesed on 08.07.2018).

20.*** REGULATION (EC) No 1223/2009 OF THE EUROPEAN PARLIAMENT AND OF THE COUNCIL of 30 November 2009 on cosmetic products, https://eur-lex.europa.eu/LexUriServ/LexUriServ.do?uri= OJ :L:2009:342:0059:0209:en:PDF (accesed on 08.07.2018).
21.JUNCAN, A. M., FETEA, F., SOCACIU, C., ENVIRON. ENG. MANAG. J., 13, 1, 2014, p. 105.

22.JUNCAN, A. M., HORGA, C. E., HODISAN, T., (2011), Studia UBB Chemia, LVI, 2, 2011, p. 195-204.

23.IWATA, H., SHIMADA, K., Formulas, Ingredients and Production of Cosmetics, Springer, Tokyo, 2013, p. 3-19.

24.LODÉN, M., MAIBACH, H. I., Treatment of Dry Skin Syndrome- The Art and Science of Moisturizers, Springer-Verlag Berlin Heidelberg, 2012, p. 3-16.

25.MORGANTI, P., PAGLIALUNGA, S., Clin. Dermatol., 26, 4, 2008, p. 392-397.

26.MORGOVAN, C., COSMA, S., BURTA, C., GHIBU, S., POLINICENCU, C., VASILESCU, D., Farmacia, 58, 4, 2010, p. 400-407.

27.LIONETTI, N., LUIGI RIGANO, L., Cosmetics, 5, 1, 2018, p. 22-32.

28.EIXARCH, H., ANDREW, D., Personal Care Magazine, 4, 2018, p. 13.

29.SAHOTA A., Sustainability: How the Cosmetics Industry is Greening Up, John Wiley \& Sons Ltd, West Sussex, 2014, p. 127-129.

30.*** https://w ww.marketresearchfuture.com/reports/cosmeticbottle-packaging-market-5133 (accesed on 12.07.2018).

31.LINTNER, K., Global Regulatory Issues for the Cosmetics Industry, $2^{\text {nd }}$ Vol., William Andrew Inc., Norwich, 2009, p. 175-186.

32.*** https://www.statista.com/statistics/735070/global-cosmeticpackaging-market-value/ (accesed on 13.07.2018).

33.ROSETTE, J. L., YABLONSKI, J., MANCUSO, S. GAURAV KALE, G., Packaging, Cosmetics, and Pharmaceuticals, in KIRK-OTHMER CHEMICAL TECHNOLOGY OF COSMETICS, J ohn Wiley $\&$ Sons, Inc., Hoboken, New Jersey, 2013, p. 729-730.

34.FARRIS, P. K., Cosmeceuticals and Cosmetic Practice, John Wiley $\&$ Sons, West Sussex, 2014, p. 17-19.

35.GIVAUDAN ACTIVE BEAUTY, MK Brochure, 2018, p. 30-48.

36.J OHNSON, B. J., LIN, B., BONGARD, J. E., Recent Pat Biotechnol., 4, 2, 2010, p. 112-24.

37.CRODAROM, MK Brochure, 2018, p. 1-2.

38.*** https://www.cosmeticseurope.eu/cosmetics-industry/ innovation-and-future-trends-cosmetics-industry/ (accesed on 14.07.2018).

39.*** The Cosmetic, Toiletry, and Fragrance Association (COLIPA), CTFA, Guidelines on stability testing of cosmetic products, 3, 2004, p. $1-8$.

40.*** The SCCS Notes of Guidance for the Testing of Cosmetic Ingredients and their Safety Evaluation 9th revision. SCCS/1564/15, revised version of 25 April 2016, p. 73-86.

41.RIASCO, B., CAPRA, P., COZZI, A. C., MANNUCCI, B., PERUGINI, P., Cosmetics, 3, 32, 2016, p. 2-12.

Manuscript received: 20.02.2019 